\title{
Assessment of intellectual capital influence on corporate value as a field for further investigations in corporate finance
}

\author{
Feruleva, Natalia V. \\ Postgraduate student, doctoral school of Economics, \\ National Research University Higher School of Economics, \\ National Research University Higher School of Economics, \\ 25/12 Bolshaya Pecherskaya, Nizhny Novgorod, Russia \\ E-mail: nferuleva@hse.ru; natasha.feruleva@mail.ru

\section{Ivashkovskaya, Irina V.} \\ Doctor of Sciences in Finance, Monetary Circulation and Credit, \\ Doctor of Sciences in Economics and National Economy Management, \\ Professor, head of School of Finance, head of corporate finance center, \\ National Research University Higher School of Economics, \\ 26 Shabolovka, Moscow, Russia \\ E-mail: iivashkovskaja@hse.ru; ivashkovskaya@yandex.ru
} 26 Shabolovka, Moscow, Russialecturer of the Department of accounting, analysis and auditing,

\begin{abstract}
This study presents the results of an empirical study analysis about the impact of intellectual capital on corporatevalue. The aim of this study is to identify the direction for research development dealing with the impact of intellectual capital on business value, financial performance indicators, and the indicators that reflect the state of the individual components and subcomponents of intellectual capital. This study used general scientific methods such as comparison, deduction, induction and analysis.

Based on the results of the literature review, it was shown that when developing a model for assessing the impact of intellectual capital on business value and the performance indicators of business activities, it is necessary to include the factors that describe the state of all the components and subcomponents of intellectual capital, as well as the synergistic effects caused by the interaction of the individual components of intellectual capital. In addition, it makes sense to include the factors that describe the state of the components of intellectual capital for prior periods of time in the model. At the present time, there is also a need for research on the evaluation of the mutual influence of the individual components and subcomponents of intellectual capital. In order to identify the industry specificity of the influence of the intellectual capital components on business value, the developed models should be tested separately using data of companies from different industries. When carrying out the analysis, it is important to take into account the factors related to the company's external environment, such as the level of economic development of the country in which the company operates, as well as fluctuations in economic activity.
\end{abstract}

Keywords: intellectual capital, financial performance, market value, empirical studies, intellectual capital components JEL: G 32, O 34 
According to the report "Supporting Investment in Knowledge Capital, Growth and Innovation", prepared by the Organization for Economic Cooperation and Development (OECD), investments made by companies in intellectual capital (IC) contribute to their growth and productivity and, in particular, due to these investments, the average productivity in the USA and the European Union has increased by $20-34 \%$ [OECD, 2013]. Moreover, the OECD states that a positive correlation also takes place between the market value of firms and investments in intellectual capital. These facts support the resource-based theory, which claims that intellectual capital is one of the most important strategic resources, which enable firms to gain a competitive advantage [Wernerfelt, 1984].

The importance of intellectual capital determines the need for the development of effective intellectual capital measurement tools. It is worth noting that already by the end of the $20^{\text {th }}$ century, researchers were focusing on the problem of intellectual capital measurement [Stewart, 1997; Pulic, 1998]. In the $21^{\text {st }}$ century, intellectual capital measurement has already become a separate area for investigations in the field of intellectual capital and continues to be under debate. Furthermore, in the $21^{\text {st }}$ century, empirical studies devoted to the interrelation between intellectual capital and company value appeared. These studies are rooted in the fundamentals of resource-based theory. In order to test the hypothesis that intellectual capital and its components influence company value, investigators received data on the state of intellectual capital through a variety of IC measurement methods, so these empirical studies are linked with research in the field of intellectual capital measurement.

Currently there is vast literature on both intellectual capital measurement [Edvinsson, 1997; Lev, 2001; Pulic, 1998; Litschka, 2006; Nazari and Herremans, 2007; Sveiby, 2010; Zegal, 2010] and the assessment of the impact of IC on corporate value and company performance operating in developed countries [Artie, 2006; Zegal, 2010; Clarke, 2011; Liu, 2009; Liu, 2017] and developing countries [Garanina, 2010; Pucar, 2012; Rizun, 2014; Singh, 2015, Andreeva, 2016]. These problems have been hotly debated time and again, so it is vital to identify the issues that still remain unsolved.

The primary aim of the present study is to review the assessment field for the influence of intellectual capital on corporate value, financial performance and the value of the IC components, with subcomponents as a special issue, and to identify potential areas for further investigation.

To achieve this aim, we are going to identify the types of empirical studies in the field of assessment of the influence of intellectual capital. We will make an attempt to analyze the methodology used to assess the influence of intellectual capital on financial performance and the corporate value of companies. In particular, we are going to review and summarize the metrics for the components and subcomponents of intellectual capital, financial performance, corporate value, the methods used in these types of investigations to measure intellectual capital the models that represent the relationships between the components of intellectual capital and corporate financial performance and value, along with the results obtained with the help of the models, methods, and metrics for both developing and developed countries. After that, we will also make an attempt to find the areas that remain under-researched and put forward ideas for further investigation.

The paper is structured as follows: in the first section, we will consider the structure of intellectual capital; the second section is devoted to the types of empirical studies in the field of assessing the influence of intellectual capital. In the third and fourth sections, we will discuss the influence of intellectual capital on financial performance and market value. The fifth section is devoted to other empirical studies in the field of assessing the influence of intellectual capital.

\section{Intellectual capital structure}

Until now, a generally accepted structure for intellectual capital has not existed. This uncertainty led to difficulties that are connected with the interpretation of results obtained by other researchers. That is why before concentrating on the problems of assessing the impact of IC on financial performance and corporate value, we will focus on the structure of IC in order to identify the key components and subcomponents that should be measured.

In this paper, we use the definition for intellectual capital pushed forward by D. Zegal and consider IC as the sum of all knowledge a company is able to use in the process of conducting business in order to create value [Zegal, 2010]. Currently, there are several points of view on the main components of intellectual capital and their hierarchy: some investigators use the scheme of Skandia Navigator and presuppose that intellectual capital can be subdivided into human and structural capital, which includes innovation and process capital [Edvinsson, 1997; Zegal, 2010; Clarke, 2011], while others identify not only human and structural, but also relational capital as an equally separate component [Sharabatia, 2013; Andreeva, 2016]. The latter point of view is also shared by the business reporting network WICI. A modified model for intellectual capital structure was also developed by E. Baiburina and I. Ivashkovskaya who stressed the importance of network capital and considered it as separate component together with human, organizational (structural) and client capital [Baiburina, 2007]. So, instead of relation capital, they consider client capital and network capital.

In spite of the fact that researchers used different terms for the intellectual capital components, the majority of them identified human, structural (organizational) and relational capital. In turn, it is possible to subdivide structural capital into innovation and process capital, and relational capital into the customer (client) and the network subcomponent. So, the structure of intellectual capital can be represented in the following way (Figure 1). 
Figure1. Taxonomy of intellectual capital

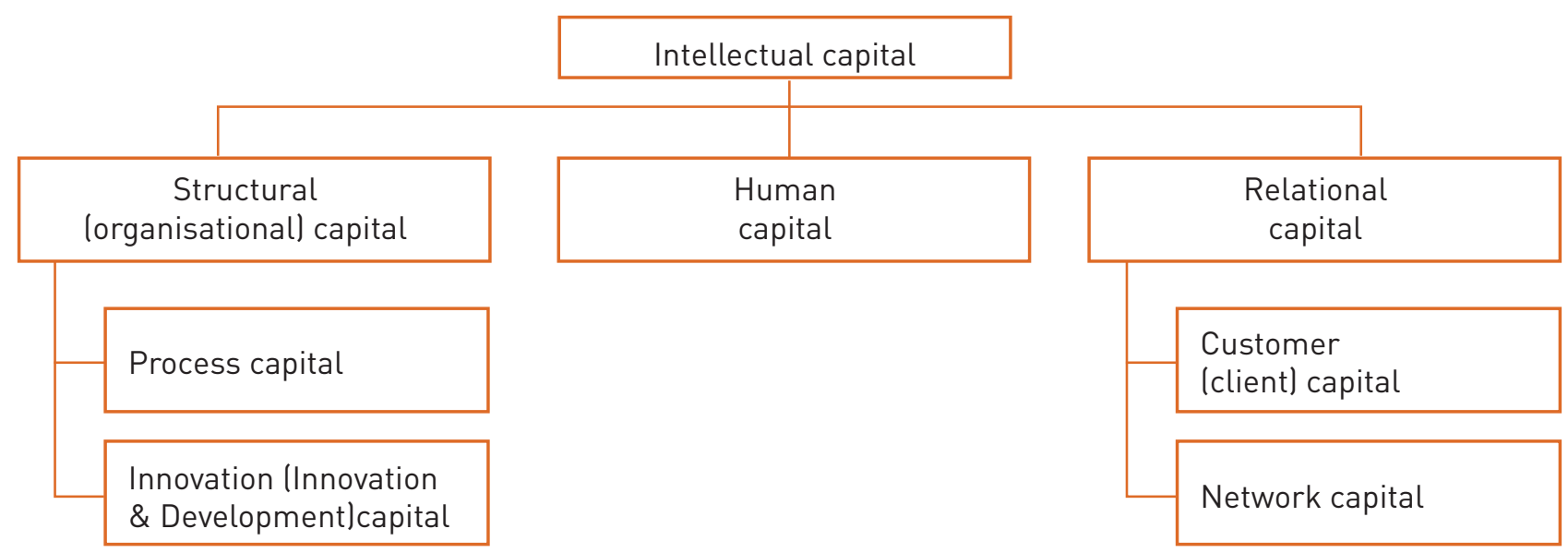

Figure 2. Types of empirical studies connected with the influence of intellectual capital on financial performance and corporate value (author classification)

\begin{tabular}{|c|c|c|c|}
\hline & \multicolumn{2}{|c|}{$\begin{array}{l}\text { Types of empirical studies in the field } \\
\text { of intellectual capital influence assessment }\end{array}$} & \\
\hline $\begin{array}{l}\text { Studies of the } \\
\text { relationship } \\
\text { between financial } \\
\text { performance and IC }\end{array}$ & $\begin{array}{l}\text { Studies of the } \\
\text { relationship } \\
\text { between market } \\
\text { value and IC }\end{array}$ & $\begin{array}{l}\text { Studies of the } \\
\text { relationship } \\
\text { between economic } \\
\text { value added and IC }\end{array}$ & $\begin{array}{l}\text { Studies of the } \\
\text { relationship } \\
\text { between the values } \\
\text { of } \mathrm{IC} \text { components }\end{array}$ \\
\hline
\end{tabular}

So, we have identified the main components and subcomponents of IC, which should be measured separately, and now we can concentrate on their influence on corporate value.

\section{Types of empirical studies in the field of assessing the influence of intellectual capital}

The classification of the components and subcomponents of intellectual capital is used by researchers when they analyze how intellectual capital, namely its components and subcomponents, influence corporate value and financial performance. Currently, there exists an enormous amount of literature on these empirical studies and we will try to identify the main types of studies in this field (Figure 2).It is worth stressing that currently most empirical studies are devoted to analyzing the impact that intellectual capital has on the financial performance and market value of companies, whereas the relationship between economic value added and intellectual capital, and the relationship between the value of the components of intellectual capital are relatively little researched. We will start with the most widespread types of empirical research and after, we will focus our attention on the problems that tend to be seldom discussed.

\section{The influence of intellectual capital on financial performance}

The issue of intellectual capital influence on companies' financial performance has been at the heart of numerous discussions [Artie, 2006; Clarke, 2011; Pucar, 2012; Kamath, 2015; Singth, 2015; Liu, 2017]. The researchers tested the hypothesis that a higher value intellectual capital and its components and subcomponents leads to a higher financial performance of companies operating in both developed (Table 1) and developing countries (Table 2). In our review, we consider the results for the developed and developing countries separately. For example, T. Andreeva, referring to the results obtained by PricewaterhouseCoopers, states that in emerging markets, the effects might be different because of political, institutional, cultural, and economic peculiarities [Andreeva, 2016]. We tried to choose studies that could demonstrate the variety of approaches used by investigators in this field. 
Table 1. The influence of intellectual capital on the financial performance of companies operating in developed countries

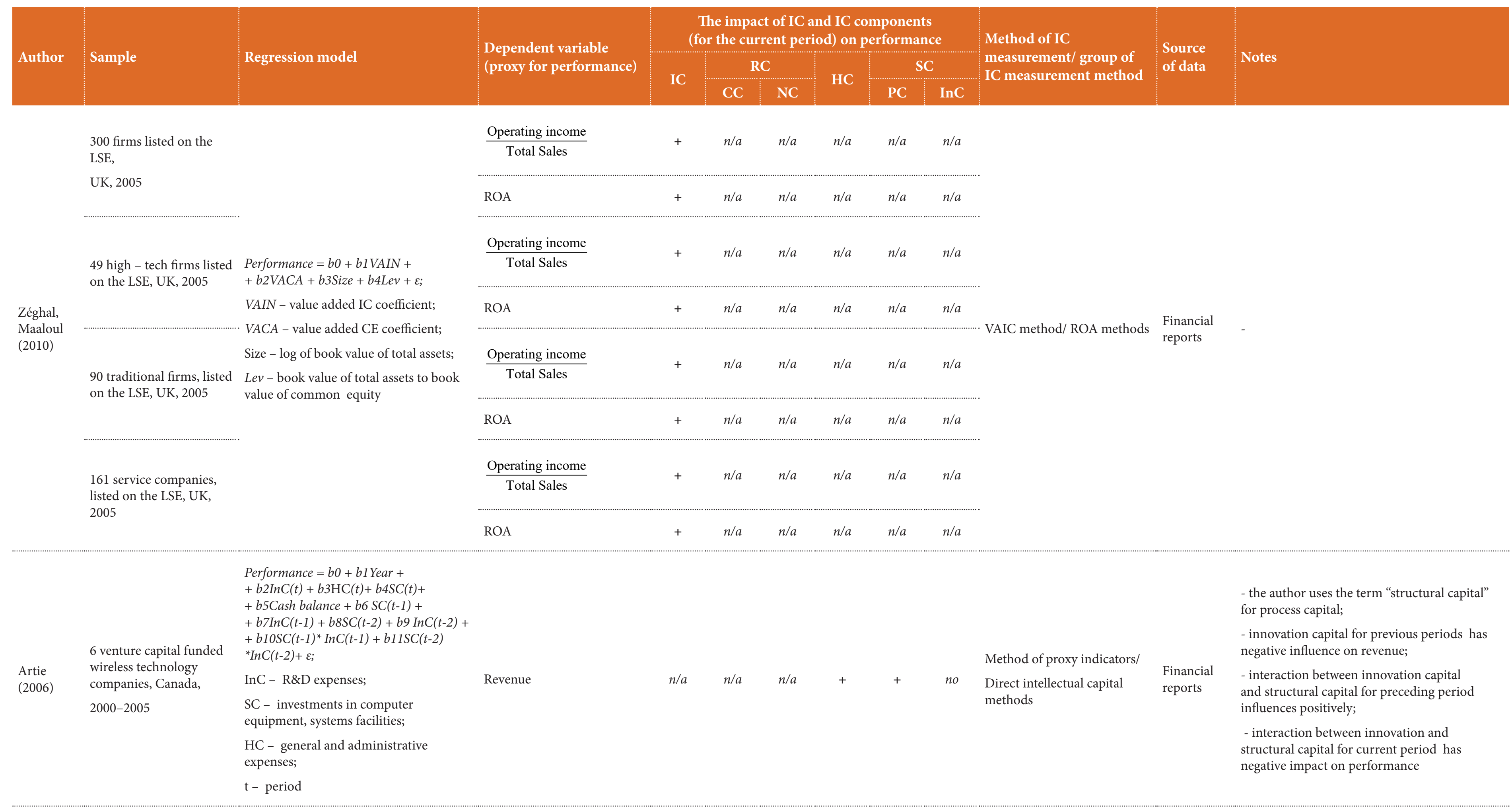




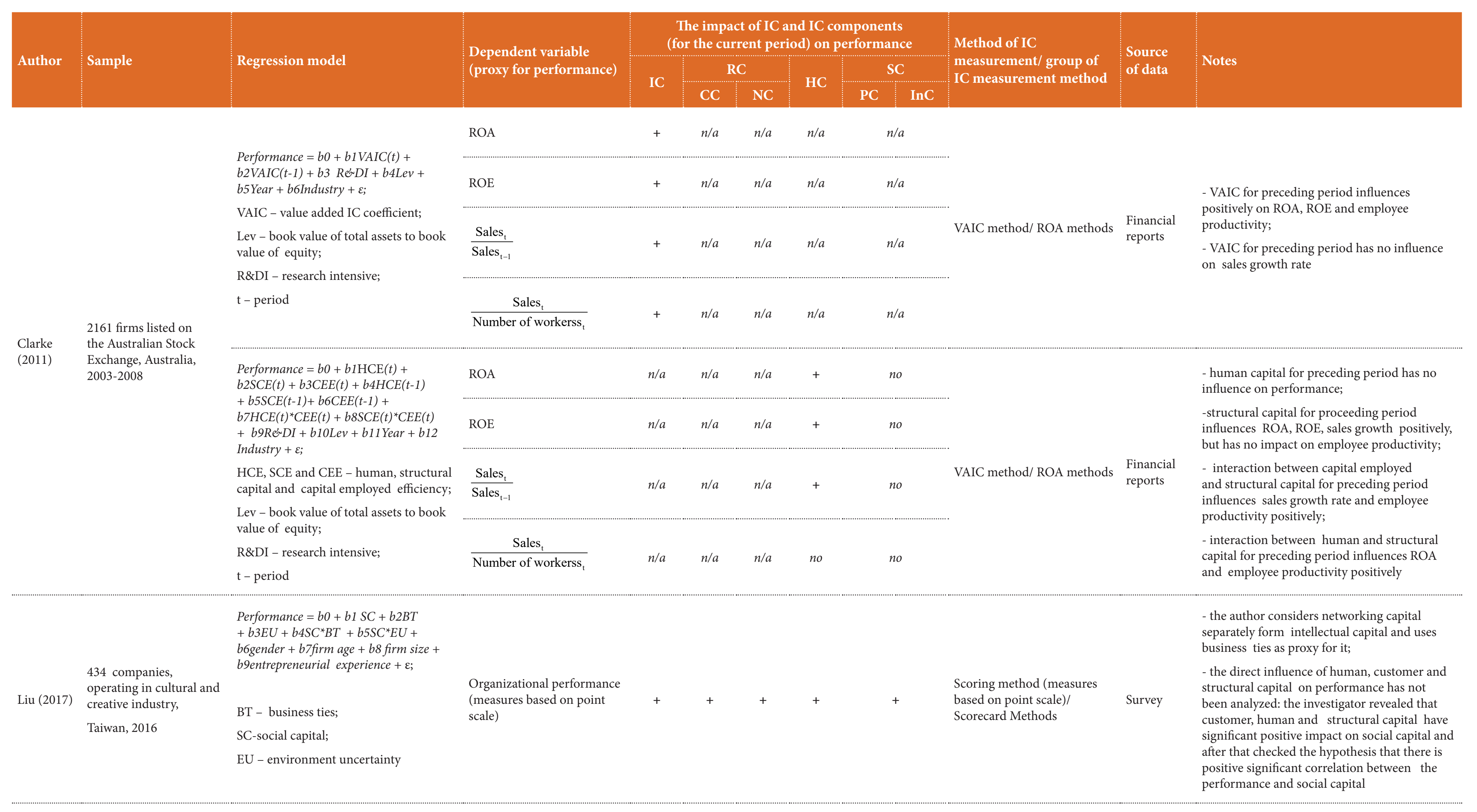

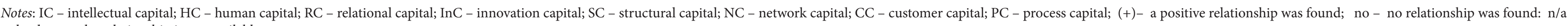
- the data on the relationship is not available. 
Table 2. The influence of intellectual capital on the financial performance of companies operating in developing countries

\begin{tabular}{|c|c|c|c|c|c|c|c|c|c|c|}
\hline \multirow[t]{3}{*}{ Author } & \multirow[t]{3}{*}{ Sample } & \multirow[t]{3}{*}{ Regression model } & \multirow{3}{*}{$\begin{array}{l}\text { Dependent } \\
\text { variable } \\
\text { (proxy for } \\
\text { performance) }\end{array}$} & \multicolumn{5}{|c|}{ The impact of IC and IC components on performance } & \multirow{3}{*}{$\begin{array}{l}\text { Method of IC measurement/ } \\
\text { group of IC measurement } \\
\text { method }\end{array}$} & \multirow[t]{3}{*}{ Source of data } \\
\hline & & & & \multirow{2}{*}{ IC } & \multirow{2}{*}{ RC } & \multirow{2}{*}{$\mathrm{HC}$} & \multicolumn{2}{|c|}{ SC } & & \\
\hline & & & & & & & PC & $\mathrm{InC}$ & & \\
\hline \multirow{6}{*}{ Pucar (2012) } & \multirow{2}{*}{$\begin{array}{l}134 \text { firms, Bosnia and } \\
\text { Herzegovina, } \\
\text { 2004-2007 }\end{array}$} & $\begin{array}{l}\text { Performance }=b 0+b 1 \mathrm{HCE}+\varepsilon ; \\
\text { Performance }=b 0+b 1 \text { HCE growth rate }+\varepsilon \\
\text { HCE }- \text { human capital efficiency }\end{array}$ & \multirow{6}{*}{$\begin{array}{l}\text { Growth rate } \\
\text { of export per } \\
\text { worker }\end{array}$} & $n / a$ & $n / a$ & no & $n / a$ & $n / a$ & \multirow{2}{*}{$\begin{array}{l}\text { VAIC method/ } \\
\text { ROA methods }\end{array}$} & \multirow{2}{*}{ Financial report } \\
\hline & & $\begin{array}{l}\text { Performance }=b 0+b 1 \text { VAIC }+\varepsilon ; \\
\text { Performance }=b 0+b 1 \text { VAIC growth rate }+\varepsilon \\
\text { VAIC - value added intellectual capital }\end{array}$ & & no & $n / a$ & $n / a$ & $n / a$ & $n / a$ & & \\
\hline & \multirow{2}{*}{$\begin{array}{l}14 \text { firms, producing food } \\
\text { and beverage, Bosnia and } \\
\text { Herzegovina, 2004-2007 }\end{array}$} & $\begin{array}{l}\text { Performance }=b 0+b 1 H C E+\varepsilon \\
\text { HCE - human capital efficiency }\end{array}$ & & $n / a$ & $n / a$ & + & $n / a$ & $n / a$ & \multirow{2}{*}{$\begin{array}{l}\text { VAIC method/ } \\
\text { ROA methods }\end{array}$} & \multirow{2}{*}{ Financial report } \\
\hline & & $\begin{array}{l}\text { Performance }=b 0+b 1 \text { VAIC }+\varepsilon \\
\text { VAIC - value added intellectual capital }\end{array}$ & & + & $n / a$ & $n / a$ & $n / a$ & $n / a$ & & \\
\hline & \multirow{2}{*}{$\begin{array}{l}12 \text { firms, manufacturing } \\
\text { furniture and other wood } \\
\text { products, Bosnia and } \\
\text { Herzegovina, 2004-2007 }\end{array}$} & $\begin{array}{l}\text { Performance }=b 0+b 1 \text { HCE growth rate }+\varepsilon \\
\text { HCE - human capital efficiency }\end{array}$ & & $n / a$ & $n / a$ & + & $n / a$ & $n / a$ & \multirow{2}{*}{$\begin{array}{l}\text { VAIC method/ } \\
\text { ROA methods }\end{array}$} & \multirow{2}{*}{ Financial reports } \\
\hline & & $\begin{array}{l}\text { Performance }=b 0+b 1 \text { VAIC growth rate }+\varepsilon \\
\text { VAIC - value added intellectual capital }\end{array}$ & & + & $n / a$ & $n / a$ & $n / a$ & $n / a$ & & \\
\hline Rizun (2014) & $\begin{array}{l}5 \text { ore mining and processing } \\
\text { plants, each company has } \\
\text { been considered separately, } \\
\text { Ukraine, 2006-2013 }\end{array}$ & $\begin{array}{l}\text { Performance }=b 0+b 1 W F+b 2 E R D+b 3 V I A \\
+b 4 E E+\varepsilon ; \\
\text { WF - wages fund; } \\
\text { ERD - expenses on R\&D; } \\
\text { VIA - residual value of intangible assets; } \\
\text { EE - expenses per employee }\end{array}$ & Net profit & $n / a$ & $n / a$ & $\begin{array}{c}+ \\
\text { (EE, } 3 \text { firms }) \\
-(E E, 1 \text { firm }) \\
-(W F, 1 \text { firm }) \\
\text { no } \\
\text { (others) }\end{array}$ & $n / a$ & $\begin{array}{c}+ \\
(E R D, 3 \text { firms }) \\
+ \\
(\text { VIA, } 1 \text { firm }) \\
\text { no } \\
\text { (others) }\end{array}$ & $\begin{array}{l}\text { Method of proxy indicators/ } \\
\text { Direct intellectual capital methods }\end{array}$ & Financial reports \\
\hline \multirow{5}{*}{$\begin{array}{l}\text { Singh, } \\
\text { Narwal (2015) }\end{array}$} & \multirow{5}{*}{$\begin{array}{l}\text { top-50 electronic companies } \\
\text { listed on NSE and Bombay } \\
\text { Stock Exchange (BSE), India, } \\
\text { 2004/2005-2013/2014 }\end{array}$} & $\begin{array}{l}\text { Performance }=b 0+b 1 \text { VAIC }+b 2 \text { DER }+ \\
\text { b3SIZE }+\varepsilon\end{array}$ & ATO & + & $n / a$ & $n / a$ & $n / a$ & $n / a$ & \multirow{2}{*}{$\begin{array}{l}\text { VAIC method/ } \\
\text { ROA methods }\end{array}$} & \multirow{2}{*}{ Financial reports } \\
\hline & & $\begin{array}{l}\text { VAIC - value added intellectual capital; } \\
\text { DER - Debt to Equity ratio; } \\
\text { SIZE - log of total assets }\end{array}$ & ROA & + & $n / a$ & $n / a$ & $n / a$ & $n / a$ & & \\
\hline & & $\begin{array}{l}\text { Performance }=b 0+b 1 H C E+b 2 S C E+ \\
b 3 C E E+b 4 D E R+b 5 S I Z E+\varepsilon\end{array}$ & ATO & $n / a$ & $n / a$ & no & \multicolumn{2}{|c|}{ no } & \multirow{3}{*}{$\begin{array}{l}\text {." VAIC method/ } \\
\text { ROA methods }\end{array}$} & \multirow{3}{*}{ Financial report } \\
\hline & & $\begin{array}{l}\text { HCE, SCE and CEE - human, structural } \\
\text { capital and capital employed efficiency; }\end{array}$ & & & & & \multirow{2}{*}{\multicolumn{2}{|c|}{ no }} & & \\
\hline & & $\begin{array}{l}\text { DER - Debt to Equity ratio; } \\
\text { SIZE - log of total assets }\end{array}$ & ROA & $n / a$ & $n / a$ & + & & & & \\
\hline
\end{tabular}




\begin{tabular}{|c|c|c|c|c|c|c|c|c|c|c|}
\hline \multirow[t]{3}{*}{ Author } & \multirow[t]{3}{*}{ Sample } & \multirow[t]{3}{*}{ Regression model } & \multirow{3}{*}{$\begin{array}{l}\text { Dependent } \\
\text { variable } \\
\text { (proxy for } \\
\text { performance) }\end{array}$} & \multicolumn{5}{|c|}{ The impact of IC and IC components on performance } & \multirow{3}{*}{$\begin{array}{l}\text { Method of IC measurement/ } \\
\text { group of IC measurement } \\
\text { method }\end{array}$} & \multirow[t]{3}{*}{ Source of data } \\
\hline & & & & \multirow{2}{*}{ IC } & \multirow{2}{*}{ RC } & \multirow{2}{*}{ HC } & \multicolumn{2}{|r|}{ SC } & & \\
\hline & & & & & & & PC & $\mathrm{InC}$ & & \\
\hline $\begin{array}{l}\text { Sharabatia, } \\
\text { Nourb, } \\
\text { Shamaric } \\
\text { (2013) }\end{array}$ & $\begin{array}{l}84 \text { companies, } \\
\text { Jordanian }\end{array}$ & $\begin{array}{l}\text { Performance }=b 0+b 1 H C+b 2 S C+b 3 R C+ \\
\varepsilon ; \\
\text { HC - human capital; } \\
\text { RC - relational capital; } \\
\text { SC - structural capital }\end{array}$ & $\begin{array}{l}\text { Performance } \\
\text { (measures based } \\
\text { on point scale) }\end{array}$ & $n / a$ & + & no & & no & $\begin{array}{l}\text { Scoring method (measures based on } \\
\text { point scale)/Scorecard Methods }\end{array}$ & Survey \\
\hline $\begin{array}{l}\text { Benebou, } \\
\text { Bouguesri } \\
\text { (2016) }\end{array}$ & $\begin{array}{l}307 \text { companies, } \\
\text { Algeria }\end{array}$ & $\begin{array}{l}\text { Performance }=b 0+b 1 H C+b 2 S C+b 3 O C+\varepsilon ; \\
\text { HC - human capital; } \\
\text { SC - social capital (relational capital in our } \\
\text { terms); } \\
\text { OC - organizational capital (structural capital } \\
\text { in our terms) }\end{array}$ & $\begin{array}{l}\text { Performance } \\
\text { (measures based } \\
\text { on point scale) }\end{array}$ & $n / a$ & + & + & & + & $\begin{array}{l}\text { Scoring method (measures based on } \\
\text { point scale)/ Scorecard Methods }\end{array}$ & Survey \\
\hline $\begin{array}{l}\text { Kamath } \\
\text { (2015) }\end{array}$ & $\begin{array}{l}30 \text { manufacturing and service } \\
\text { firms, } \\
\text { India, 2008/2009-2012/2013 }\end{array}$ & $\begin{array}{l}\text { Performance }=b 0+b 1 H C E+b 2 S C E+ \\
b 3 C E E+\varepsilon ; \\
\text { HCE, SCE and CEE - human, structural } \\
\text { capital and capital employed efficiency }\end{array}$ & ROA & $n / a$ & $n / a$ & + & & - & $\begin{array}{l}\text { VAIC method/ } \\
\text { ROA methods }\end{array}$ & Financial reports \\
\hline \multirow[t]{2}{*}{$\begin{array}{l}\text { Omodero } \\
\text { et al. } \\
(2016)\end{array}$} & \multirow[t]{2}{*}{$\begin{array}{l}10 \text { listed firms, Nigeria, } \\
2011-2015\end{array}$} & \multirow{2}{*}{$\begin{array}{l}\text { Performance }=b 0+b 1 P B C+\varepsilon \text {; } \\
\text { PBC - Personnel Benefit Costs (connected } \\
\text { with education and training undertaken by } \\
\text { individuals or groups of workers) }\end{array}$} & Profit after Tax & $n / a$ & $n / a$ & + & & $n / a$ & \multirow[t]{2}{*}{$\begin{array}{l}\text { Method of proxy indicators/ } \\
\text { Direct IC methods }\end{array}$} & \multirow[t]{2}{*}{ Reports of firms } \\
\hline & & & Turnover & $n / a$ & $n / a$ & + & & $n / a$ & & \\
\hline $\begin{array}{l}\text { Andreeva, } \\
\text { Garanina } \\
\text { (2016) }\end{array}$ & $\begin{array}{l}240 \text { manufacturing } \\
\text { companies, } \\
\text { Russia, } \\
2015\end{array}$ & $\begin{array}{l}\text { Performance }=b 0+b 1 H C+b 2 R C+b 3 S C+\varepsilon \\
\text { HC - structural capital; } \\
\text { RC - relational capital; } \\
\text { SC - structural capital }\end{array}$ & $\begin{array}{l}\text { Performance } \\
\text { (measures based } \\
\text { on point scale) }\end{array}$ & $n / a$ & no & + & & + & $\begin{array}{l}\text { Scoring method (measures based on } \\
\text { point scale)/ } \\
\text { Scorecard Methods }\end{array}$ & Survey \\
\hline
\end{tabular}

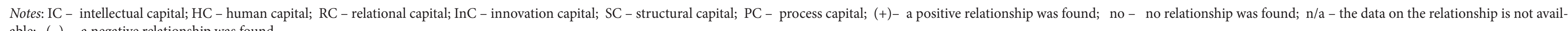
able; (-) - a negative relationship was found. 
When the hypothesis was tested on the sample of companies operating in developed countries, it was found that intellectual capital had a positive significant influence on financial performance. The same dependence was identified for human capital. As for structural capital, the results were quite controversial. In some cases, there was no significant correlation; while in others, the structural capital had a positive impact on performance. Perhaps, the problem is linked to the method used to evaluate structural capital: M. Clarke employed the VAIC method, which is less effective for structural capital valuation [Basuki, Kusumawardhani, 2012]. In spite of criticism for the VAIC method, it remains one of the most widespread tools used to measure intellectual capital components for further empirical investigation. But it does not enable measurement of the subcomponents of intellectual capital and it might be better to use an extended VAIC method in this case. The main advantage of this method is the opportunity to evaluate two components of IC, such as human and relational capital, and the subcomponents of structural capital (process and innovation capital) [Nazari, 2007]. Thus, employing this method makes it possible to assess the influence of human, relational and structural capital separately.

It is worth noting that for developed countries, scientists have already checked the hypothesis that the intellectual capital components for the preceding periods influence performance, but the results were controversial because in some cases there was a positive correlation [Clarke, 2011] whereas in others there was a negative one [Artie, 2006]. No doubt, this dependence should be investigated carefully because intellectual capital brings in benefits for the long-term. Furthermore, attempts to take the interrelations between the intellectual capital components into account have already been made.

One of the most promising studies was conducted by C. Liu, who analyzed business ties, and found that they positively influence the performance of Taiwanese firms [Liu, 2017]. The results proved the importance of network capital for firms.

As for the results from the sample of companies operating in emerging markets, they are more controversial in comparison with the findings for the developed markets. Thus, structural capital had a significant positive impact on the financial performance of manufacturing companies in Russia [Benebou, 2016; Andreeva, 2016] and a negative impact in India [Kamath, 2015]. At the same time, R. Singth did not identify either a positive or a negative correlation on the sample of electronic companies in India [Singth, 2015]. Human and relational capital in some cases had a positive influence, whereas, in others, a significant correlation was not found.

To our mind, it seems reasonable to continue developing models for both developed and developing countries, while taking into consideration the value of all the intellectual capital components for the current and preceding periods and the interrelations between IC components. It is vital to consider the interrelations between intellectual capital components because their synergistic effect provides competitive advantages [Rodov, 2002]. Furthermore, intangible investments show synergies both with other intangible investments and with tangible assets [Haskel, Westlake, 2018]. So, it is important to implement these synergistic effects in the models. It is also essential to analyze the relationship for each industry separately because in various industries, the role of each IC component may differ greatly.

\section{The influence of intellectual capital on market value}

According to the OECD report, there is a positive correlation between the market value of firms and investments in intellectual capital [OECD, 2013]. The OECD conducted research mainly for developed markets, and it is of interest whether there is a similar correlation for emerging markets. The matter of interest is that the quality of intellectual capital for firms operating in developed markets is higher [Pucar, 2012; Andreeva, 2016]. Moreover, the level of corporate transparency is also higher in comparison with companies operating in emerging markets. For example, according to the results from the Russian Regional Integrated Reporting Network, the level of corporate transparency in Russia is quite low [RRN, 2015]. That is why in this paper, we focused mainly on the results of the emerging market investigations (Table 3-4).

It was found that in the emerging markets, intellectual capital, in most cases, did not have any influence on market value. However, researchers identified that structural capital had a positive impact on the market value of Russian energy companies, and that relational capital is important for Russian metallurgy firms [Garanina, 2010]. Human capital has a positive influence on the market to book value for electronic companies in India [Singth, 2015].

One of the most promising research papers in this area was prepared by D. Liu, who evaluated the intellectual capital components with the help of proxy indicators on the basis of publicly available data. After that, he investigated the relationship between all the indicators and the share price and revealed a positive significant correlation [Liu, 2009] (Table 4). However, the model also had shortcomings such as the fact that Liu avoids using control variables such as the debt to equity ratio, the stock market index, and the size of the firm, despite the importance of these parameters.

We did not review any studies in which the researcher considered the relation between network capital and market value, so this question should be considered in further studies. We presupposed that investigators also ought to continue developing models for firms operating in various industries, taking into consideration the value of all the intellectual capital components, the interrelation between IC components, and industry specificity. It is also important to analyze the relationships between the intellectual capital components and the market value for developed and emerging markets separately. 
Table 3. The influence of intellectual capital on the market value of companies operating in emerging markets

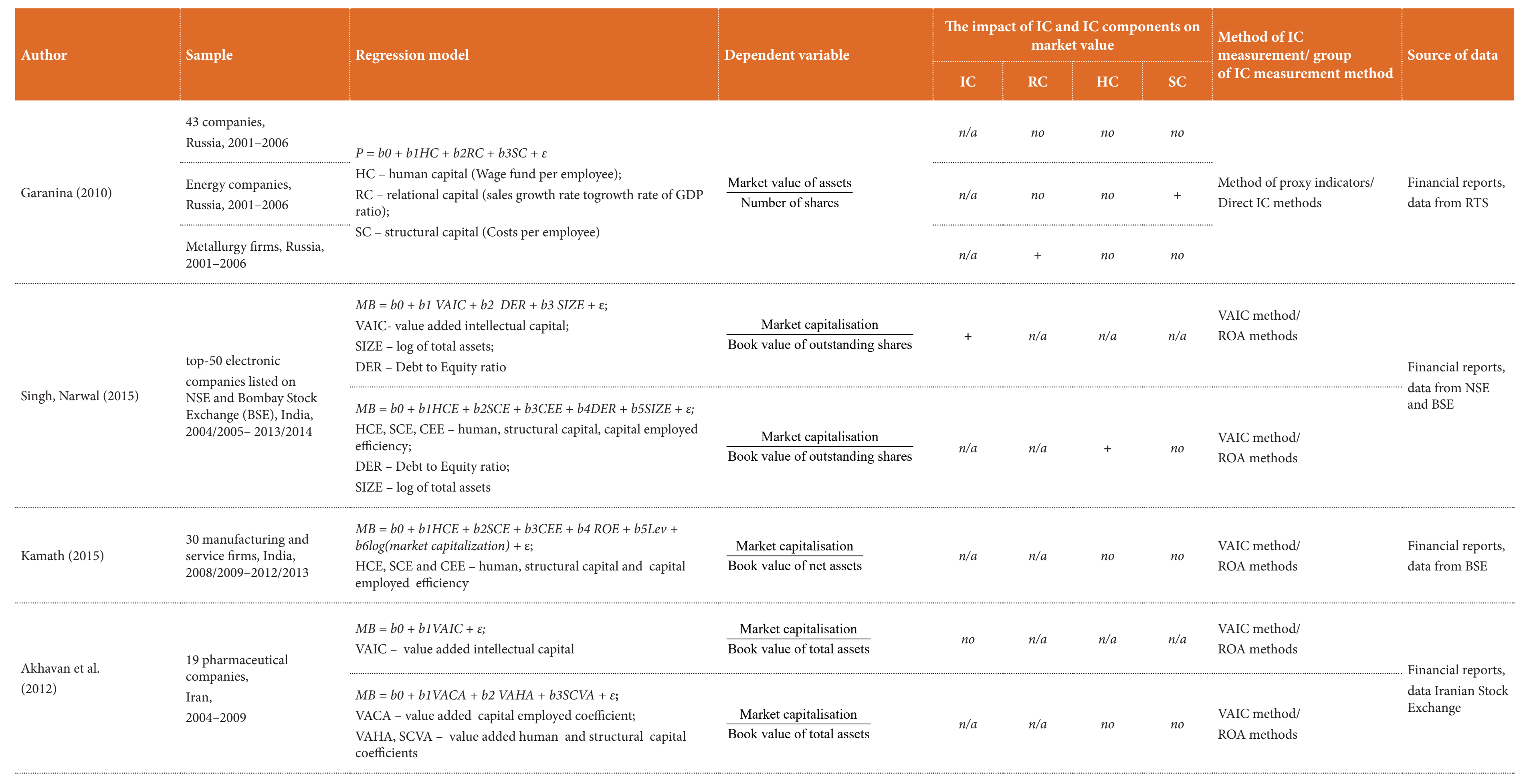

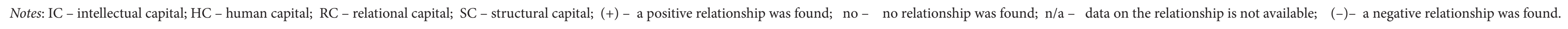




\section{Table 4. The influence of intellectual capital on the market value of Taiwan IT corporations}

\begin{tabular}{|c|c|c|c|c|c|c|c|c|c|c|}
\hline \multirow{3}{*}{ Author } & \multirow{3}{*}{ Sample } & \multirow{3}{*}{ Dependent variable } & \multirow{3}{*}{ Regression model } & \multicolumn{5}{|c|}{$\begin{array}{l}\text { The impact of IC and IC components (for the } \\
\text { current period) on market value }\end{array}$} & \multirow{3}{*}{$\begin{array}{l}\text { Method of IC } \\
\text { measurement/ group } \\
\text { of IC measurement } \\
\text { method }\end{array}$} & \multirow{3}{*}{ Source of data } \\
\hline & & & & \multicolumn{2}{|c|}{$\mathrm{RC}$} & \multirow{2}{*}{$\mathrm{HC}$} & \multicolumn{2}{|c|}{ SC } & & \\
\hline & & & & $\mathrm{CC}$ & $\mathrm{NC}$ & & PC & InC & & \\
\hline \multirow{5}{*}{$\begin{array}{l}\text { Liu et al. } \\
\text { (2009) }\end{array}$} & \multirow{5}{*}{$\begin{array}{l}505 \text { IT corporations } \\
\text { listed on the Taiwan } \\
\text { Stock Exchange } \\
\text { 2001-2005 }\end{array}$} & \multirow{5}{*}{$\begin{array}{l}\text { Share price of a closing } \\
\text { quotation of common } \\
\text { stock at the end of the } \\
\text { period }\end{array}$} & $\begin{array}{l}P=b 0+b 1 X^{\alpha}+b 2 P M C+b 3 P M S+b 4 A D V+b 5 R G+b 6 B V+\varepsilon ; \\
X^{\alpha}-\text { current EPS; } \\
\text { BV - book value of shares; PMC, PMS - proportion of major customers, } \\
\text { suppliers; } \\
\text { ADV - advertising expenses on share; } \\
\text { RG - revenue growth rate }\end{array}$ & $\begin{array}{c}+ \\
\text { (only } \\
\text { PMC) }\end{array}$ & $n / a$ & $n / a$ & $n / a$ & $n / a$ & \multirow{5}{*}{$\begin{array}{l}\text { Method of proxy indicators/ } \\
\text { Direct IC methods }\end{array}$} & \multirow{5}{*}{$\begin{array}{l}\text { Annual reports, prospectus, } \\
\text { Taiwan Economic Journal data } \\
\text { bank, Taiwan patent network, } \\
\text { prospectus Data on Taiwan Stock } \\
\text { exchange }\end{array}$} \\
\hline & & & $\begin{array}{l}P=b 0+b 1 X^{\alpha}+b 2 Y C E+b 3 M E P E+b 4 B V+\varepsilon \\
X^{\alpha}-\text { current EPS; } \\
\text { YCE - year of establishment; } \\
\text { MEPE - managerial expenses on employee }\end{array}$ & $n / a$ & $n / a$ & $n / a$ & $\begin{array}{c}+ \\
\text { (only } \\
\text { MEPE) }\end{array}$ & $n / a$ & & \\
\hline & & & $\begin{array}{l}P=b 0+b 1 X^{\alpha}+b 2 P A T+b 3 R D D+b 4 B V+\varepsilon ; \\
X^{\alpha}-\text { current EPS; } \\
\text { PAT - number of patents; } \\
\text { RDD - R\&D intensity }\end{array}$ & $n / a$ & $n / a$ & $n / a$ & $n / a$ & + & & \\
\hline & & & $\begin{array}{l}P=b 0+b 1 X^{\alpha}+b 2 R P E+b 3 R H E+b 4 A Y+b 5 A A+b 6 B V+\varepsilon ; \\
X^{\alpha}-\text { current EPS; } \\
\text { RPE-employees productivity; } \\
\text { RHE - share of employees with at least college educational level; } \\
\text { AY - average working experience; } \\
\text { AA - average age of employees }\end{array}$ & $n / a$ & $n / a$ & $\begin{array}{c}+ \\
\text { (RPE } \\
\text { only) }\end{array}$ & $n / a$ & $n / a$ & & \\
\hline & & & $\begin{array}{l}P=b 0+b 1 X^{\alpha}+b 2 P A T+b 3 R D D+b 4 R P E+b 5 B V+\varepsilon ; \\
B V-\text { book value of shares; } \\
X^{\alpha}-\text { current EPS; } \\
\text { RPE - employees productivity; } \\
\text { PAT - number of patents; } \\
\text { RDD - R\&D intensity }\end{array}$ & $n / a$ & $n / a$ & + & $n / a$ & + & & \\
\hline
\end{tabular}

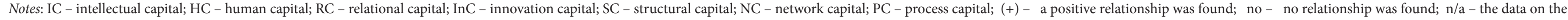
relationship is not available; (-)- a negative relationship was found. 


\section{Other empirical studies in the field of assessing the influence of intellectual capital}

Despite the fact that investigators often claim that intellectual capital is one of the key value drivers [Edvinsson, 1997; Daum, 2001; Liu, 2009; Andreeva, 2016], this issue, which is related to the impact of intellectual capital on a firm's economic value added, tends to be seldom discussed in the literature. One of the most promising studies in this field was conducted by E. Shakina and A. Barajas, who demonstrated with a sample of 1,600 European companies how the choice of an innovative profile influences both economic and market value added during pre-crisis, crisis, and post-crisis periods [Shakina, Barajas, 2015]. In order to determine the profile of a company, they analyzed the capability of human resources, management, customer loyalty, the network, innovation and internal processes. Employing the simultaneous equations model, they identified that an innovative profile enables faster recovery after a crisis but does not give any advantages in other periods of time. The results contradict the notion that intellectual capital is the most important factor of value creation in pre-crisis and crisis periods. To our mind, in further investigations, it would be vital to analyze the influence of the intellectual capital components on economic value added in the different phases of an economic cycle for the various industries separately in order to determine the conditions in which intellectual capital ceases to be a competitive advantage. It is also important to consider alternative proxies for evaluating the components of intellectual capital in order to identify which of them better reflects the state of intellectual capital

Another problem in need of analysis is connected to the relationship between the values of the intellectual capital components. The idea is that human capital, structural capital, and relational capital all enhance each other. Thus, the researcher N. Bontis identified that human capital depends on structural capital [Bontis, 1998]. The investigator R. Stoi states that without corporate culture, human capital cannot be exploited perfectly and without order processing, it is impossible to build a customer base [Stoi, 2003]. So, structural capital has influence on both human and relational capital.

The hypothesis that all intellectual capital components have an impact on each other was tested in paper written by L. Bollen. He considered intellectual property separately from human, relational, and structural capital and stressed that intellectual property was no less important than other components of intellectual capital [Bollen, 2005]. From a sample of 41 German pharmaceutical companies, he found that each component of intellectual capital had a significant positive influence on other IC components.

W. Artie checked the hypothesis that links the influence of the intellectual capital components with relational capital, using a sample of six wireless technology companies who are based in Canada [Artie, 2006]. He claimed that the relational capital for such companies is a result of the interaction between three components of intellectual capital, such as structural, human and innovation capital. The investigator considered innovation capital separately from structural capital and used the research and development expenses as a proxy. W. Artie identified a positive correlation between relational capital, and both human and structural capital. As for innovation capital, its impact on relational capital was not identified. The author also made an attempt to evaluate the influence of a joint effect between innovation and structural capital (the interaction between innovation capital and structural capital) on relational capital. The results were surprising: a negative correlation between the value of this parameter, for the current period, and relational capital was found, and a positive correlation between the value of this parameter, for the preceding period, and relational capital was found.

Currently, investigators also made an attempt to reveal the correlation between the intellectual capital components, or to be more precise, the correlation between proxies that describe intellectual capital. In particular, C. Hsu identified that an increase in R\&D intensity (structural capital, innovation subcomponent) leads to increased transparency (structural capital, process subcomponent) for high tech companies. [Hsu, 2016]. However, the question of causality still remains unsolved: process capital may also influence innovation for one, and women may simply choose companies with a high level of innovation rather than be the cause of their innovativeness.

We believe that it makes sense to investigate the interrelation between the intellectual capital components carefully, checking the hypotheses, put forward by researchers, not only on the sample of innovative companies, but also on the samples of firms operating in other industries. It is also important to consider whether this interference continues to remain during the years of economic crisis.

The hypotheses, put forward by scientists who deal with empirical research in the field of intellectual capital measurement, should be also checked on both the sample of companies operating in developed countries and the sample of firms operating in emerging countries.

\section{Conclusion}

Based on the results of the review, we have made an attempt to open the prospects for further studies in the field of assessment of the impact of intellectual capital (IC) on corporate value and performance. We systemized the empirical research in the field of assessing the influence of intellectual capital and it was identified that there are four main types of such studies:

1) The relationship between the financial performance of a company and intellectual capital.

2) The relationship between corporate market value and intellectual capital. 
3) The relationship between the economic value added and intellectual capital.

4) The relationship between the values of the intellectual capital components.

Because of the inconsistency of the results connected to the influence of the intellectual capital components on financial performance and corporate value, this problem should be investigated carefully for firms operating in developed and developing countries. It is worth noting that when elaborating models in order to assess the influence of intellectual capital on financial performance and the value of a company, it seems reasonable to employ scorecard methods for the measurement of the IC components and subcomponents. When each component and subcomponent of intellectual capital is measured with the help of proxy indicators, it becomes possible to take into consideration and identify the role of each IC component and subcomponent in the value creation process.

Moreover, investigators ought to take into consideration the state of intellectual capital in the preceding periods because intellectual capital brings benefits in the long run. It is also important to analyze the influence of intellectual capital in the various industries separately because the state of intellectual capital in different industries is described with the help of not only general, but also of specific indicators connected with the peculiarities of each industry. The phases of an economic cycle also play a great role because they may differ greatly.

It is important to concentrate not only on the problem of the interrelation between corporate value, performance and intellectual capital, but also to analyze the relationship between the intellectual capital components. It seems reasonable to elaborate the models that include the factors associated with all the intellectual capital subcomponents and their interrelations, which are no less important indicators. The hypotheses should be tested separately on the samples of companies operating in developed and developing countries.

It is worth noting that the problem of the interrelation between network capital and corporate value, financial performance, and the value of intellectual capital components continues to remain under-researched and deserves a closer examination.

\section{References}

Akhavan, P., Mehralian, G., Rasekh, H., Sadeh, M. (2012) The impact of intellectual capital efficiency on market value: An Empirical Study from Iranian Pharmaceutical Companies. Iranian Journal of Pharmaceutical Research (IJPR), vol. 11, no. 1, pp. 195-207.

Andreeva, T., Garanina, T. (2016) Do all elements of intellectual capital matter for organizational performance? Evidence from Russian context. Journal of Intellectual Capital, vol. 17, no. 2, pp. 397-412.
Artie, W. (2006) Reporting intellectual capital flow in technology-based companies: Case studies of Canadian wireless technology companies. Journal of Intellectual Capital, vol. 7, no. 4, pp. 492-510.

Baiburina, E., Ivashkovskaya. I. (2007) Rol intelectualnogo capitala v sozdanii stoimosti rossiyskih kompanii [The role of intellectual capital in value creation process of Russian companies]. Vestnik Finansovoi Akademii, no. 4, pp. 53-62 (in Russ).

Basuki, B., Kusumawardhani, T. (2012) Intellectual Capital, Financial Profitability, and Productivity: An Exploratory Study of the Indonesian Pharmaceutical Industry. Asian Journal of Business and Accounting, no. 5(2), pp. 41-68.

Benebou, D. (2016) The Impact of the Intellectual Capital on Business Performance: Evidence from the Algerian Companies. International Journal of Engineering, Business and Enterprise Applications, no. 16 (1), pp. 16-23.

Bollen, L. Vergauwen, P., Schnieders, S. (2005) Linking intellectual capital and intellectual property to company performance. Management Decision, vol. 43, no. 9, pp. 1161-1185.

Bontis, N. (1998) Intellectual capital: an exploratory study that develops measures and models. Management Decision, vol. 36, no. 2, pp. 63-76.

Clarke, M., Seng D., Whiting, R. (2011) Intellectual capital and firm performance in Australia. Journal of Intellectual Capital, vol. 12, no. 4, pp. 505-530.

Garanina, T. (2010) Nematerialnye aktivy i intellektualnyi kapital: rol v sozdanii cennosti kompanii [Intangible assets and intellectual capital: the role in corporate value creation process]. Vestnik SPbSU. Seria Menedzhment, no. 2, pp. 17-44 (in Russ).

Daum, J. (2001) Werttreiber Intangible Assets: Brauchen wir ein neues Rechnungswesen und Controlling? URL:// www.juergendaum.com/articles/IA_Controlling_d.pdf (accessed: 05.03. 2017).

Dzinkowski, R. (2000) The measurement and management of Intellectual Capital: an introduction. Management Accounting (UK), vol. 78, no. 2, pp. 32-36.

Edvinsson, L. (1997) Developing intellectual capital at Skandia. Long Range Planning, vol. 30, no. 3, pp. 266-373.

Haskel, J., Westlake, S. (2018) Capitalism without capital: the rise of the intangible economy. Princeton University Press, p. 278.

Hsu, C., Lai, S., Li, H. (2016) Institutional ownership and information transparency: Role of technology intensities and industries. Asia Pacific Management Review, no. 21, pp. 26-37.

Ilyin, D.S. (2014) The impact of intellectual capital on companies' performance: evidence from emerging markets // Journal of corporate finance, 4(32), pp. 46-66. 
Intellectual Property and the U.S. Economy: 2016 Update. 2016. URL: https://www.uspto.gov/sites/default/files/ documents/IPandtheUSEconomySept2016.pdf (accessed: 10.08. 2017).

Ivashkovskaya, I. (2009) Modelirovanie stoimosti kompaniji. Strategicheskaya otvetstvennost' soveta directorov [Modelling of company value. Strategic reporting of board of directors]. M.: INFRA-M (in Russ).

Kamath, G. (2015) Impact of Intellectual capital on Financial Performance and Market Valuation of Firms in India. International Letters of Social and Humanistic Sciences, vol. 48, pp. 107-122.

Lev, B. (2001) Intangibles: Management, Measurement and Reporting. Washington, DC, Brookings Institution Press.

Lev, B., Gu, F. (2016) The End of Accounting and The Path Forward for Investors and Managers. Wiley, p. 288.

Litschka, M., Markom, A., Schunder, S. (2006) Measuring and analysing intellectual assets: an integrative approach. Journal of Intellectual Capital, vol. 7, no. 2, pp. 160-173.

Liu, C. (2017) The relationships among intellectual capital, social capital, and performance - The moderating role of business ties and environmental uncertainty. Tourism Management, pp. 553-561.

Liu, D., Tseng, K., Yen, S. (2009) The incremental impact of intellectual capital on value creation. Journal of Intellectual Capital, vol. 10, no. 2, pp. 260-276.

Nazari, J., Herremans, I. (2007) Extended VAIC model: measuring intellectual capital components. Journal of Intellectual Capital, vol. 8, no. 4, pp. 595-609.

New sources of growth: knowledge-based capital - key analyses and policy conclusions - synthesis report, OECD. 2013. URL: https://www.oecd.org/sti/inno/knowledgebased-capital-synthesis.pdf (accessed: 08.08.2017).

Nimtrakoon, S. (2015) The relationship between intellectual capital, firms' market value and financial performance: Empirical evidence from the ASEAN. Journal of Intellectual Capital, vol. 16, no. 3, pp. 587-618.

OECD (2013) Supporting Investment in Knowledge Capital, Growth and Innovation. OECD Publishing. URL: http://dx.doi.org/10.1787/9789264193307-en (accessed: 14.12.2017).

Pucar, S. (2012) The influence of intellectual capital on export performance. Journal of Intellectual Capital, vol. 13, no. 2, pp. 248-261.

Pulic, A. (1998) Measuring the performance of intellectual potential in a knowledge economy (paper presented at 2nd McMaster World Congress).
Rizun, M. (2014) Intellectual capital as a key factor of business-processes at mining enterprises.

Rodov, I., Leliaert, Ph. (2002) FiMIAM: financial method of intangible assets measurement. Journal of Intellectual Capital, vol. 3, no. 3, pp. 323--336.

Roos, G., Roos, J. (1997) Measuring your company's intellectual performance. Long Range Planning, vol. 30, no. 3, pp. 413-426.

RRN (2015) Research on corporate transparency of Russian companies. 2015. URL: http://transparency2015. downstream.ru/\#/en/1394 (accessed: 18.02. 2017).

Shakina, E., Barajas, A. (2015) Intangible-intensive profile of a company: the key to outperforming. Journal of Intellectual Capital, vol. 16, no. 4, pp. 1-25.

Sharabatia, D. (2013). The impact of intellectual capital on Jordanian telecommunication companies' business performance. American Academic \& Scholarly Research Journal. vol. 5, no. 3, pp. 32-46.

Singh, R., Narwal, K. (2015) Intellectual capital and its consequences on company performance: a study of Indian sectors. Int. J. Learning and Intellectual Capital, vol. 12, no. 3, pp. 300-322.

Stewart, T. (1997) Intellectual Capital: The New Wealth of Organisation. London.

Stoi, R. (2003) Controlling von Intangibles, Identifikation und Steuerung der immateriellen Werttreiber. Controlling, no. 15. pp. 175-183.

Sveiby, K. (2010) Methods for measuring intangible assets. URL: http://tekobooks.com/download/methods-formeasuring-intangible-assets-sveiby/ (accessed: 01.02.2017).

Sydler, R. (2014) Measuring Intellectual Capital with Financial Figures: Can We Predict Firm Profitability? European Management Journal, no. 32, pp. 244-259.

Wernerfelt, B. (1984) A Resource-Based View of the Firm. Strategic Management Journal, vol. 5, no. 2, pp. 171-180.

WICI intangibles reporting framework (2016). URL: http://www.wici-global.com/wp-content/ uploads/2016/09/WICI-Intangibles-ReportingFramework_ver-1.0.pdf (accessed 06.09.2017).

Ze'ghal, D., Maaloul, A. (2010) Analysing value added as an indicator of intellectual capital and its consequences on company performance. Journal of Intellectual Capital, vol. 11 , no. 1, pp. 39-60. 